\title{
Evden Çalışmada Sirkadiyen Aydınlatmanın Çalışma Verimliliğine Etkisi
}

\author{
Cem DOĞAN ${ }^{1}$
}

\section{Öz}

Konut mekanlarındaki çalışma alanları kapsamında, esnek çalışma biçimi olarak giderek yaygınlaşan evden çalışma yöntemi incelenmiştir. Donatı sistemi olarak sirkadiyen aydınlatmanın evden çalışma mekanlarında insan biyolojisi ile ilişkisi araştırılmıştır. Evden çalışma düzeninde iç mekân tasarım kurgusu açısından, çalışma alanları içinde yer alan tasarım yaklaşımları ele alınarak mekân çözümlemeleri, çalışma verimi, kişinin konsantrasyonu ve konforu açısından değerlendirilmektedir. İncelemeler sonucunda, evden çalışma konut tasarımlarının güncel yaklaşım ölçütleri ve önemli tasarım faktörlerinden olan aydınlatmanın değerlendirilmesi yapılmaktadır. Sirkadiyen ritim ve bu ritmi etkileyen faktörlerin "Evden çalışanların sirkadiyen ritminin aydınlatma ile tetiklenme etkisi bireyin çalışma performansını artırabilir." hipotezinin geçerliliği yapılan araştırmalar ve literatür taraması ile elde edilen bilgiler doğrultusunda incelenmiştir.

Anahtar Kelimeler: Sirkadiyen Ritim, Evden Çalışma, Çalışma Verimi, Mekan Tasarımı

\section{The Effect of Circadian Lighting on the Work Performance in Home Offices}

\begin{abstract}
Within the scope of working areas in residential spaces, the home-office working method, which is becoming more common as a flexible working style, has been examined The relationship between circadian lighting as a reinforcement system and human biology in working places from home has been investigated. In terms of the interior design setup of the home offices, the design approaches in the working areas are taken into consideration, and their spatial solutions are evaluated from the point of working efficiency, concentration and comfort of the person. As a result of the examinations, the current approach criteria of home-office designs and the evaluation of lighting, which is one of the important design factors, within the framework of human beings are made. Circadian rhythm and factors affecting this rhythm; " The effect of triggering the circadian rhythm of home workers by lighting can increase the individual's working performance." The accuracy of the hypothesis was questioned in line with the information obtained through research and literature review.
\end{abstract}

Keywords: Circadian Rhythm, Home Office, Working Efficiency, Interior Design

\footnotetext{
1 Mimar Sinan Güzel Sanatlar Üniversitesi, Mimarlık Fak., İç Mimarlık Bölümü

*Igili yazar/Corresponding author: cemdogan67@yahoo.com

Gönderim Tarihi / Received Date: 27.03.2021

Kabul Tarihi / Accepted Date: 04.08.2021
} 


\section{Giriş}

Tarihsel süreçte, konutların dış cephesi bulunan giriş katlarının işyeri işlevi ile kullanıldığı görülmektedir. Zamanla iş hacmi büyüdükçe yeni mekân gereksinimi ortaya çıkmış ve sadece ofis alanları olarak kullanılacak binalar tasarlanmaya başlanmıştır. Aynı zamanda çalışma alanları ve yönteminde görülen değişim nedeni ile çalışma düzeni için yeni arayışlara yönelinmiş ve bunlara göre denemeler gerçekleştirilmiştir.

"Büro ve ofis kelimelerinin sözlük anlamına bakıldığında, Türk Dil Kurumu sözlüğüne göre, büro kelimesinin 1. anlamı; çalışma odası, yazıhane, 2. anlamı; danışma ve yazı işlerinin yürütüldüğü işyeri, 3. anlamı; bölüm, şube, 4. anlamı; yazı masası olarak tanımlanmaktadır. Kökeni Fransızca Bureau'dur. Ofis kelimesinin anlamı ise yine Ingilizce Office kelimesinden gelmekte işyeri, daire, büro anlamına gelmektedir." (Altınkoç, 2005, s.2). İnsanın günlük yaşamının büyük bir bölümünü geçirdiği çalışma alanlarının zamanla ofis mekanlarından konut içerisine geçişi, belirli değişimlere uğrayarak günümüzdeki haline gelmiştir.

"Bilgiye istenilen her yerden ve istenilen zamanda ulaşmanın mümkün hale geldiği günümüzde, bilgi kapalı mekânların sınırlarını aşarak mesleki ve sosyal yaşamın her alanına çok çabuk ve etkin bir biçimde dâhil edilebilir bir hal almıştır." (Çelebi Şeker, Aytar Sever, 2019, s. 534)

Teknoloji ve sanayinin gelişmesiyle birlikte ofis mekânlarında hızlı bir değişim görülmüştür. Zaman kavramının insan hayatında önemli yer tutması, çalışma performansı, verimlilik, sürdürülebilirlik gibi kavramların, çağdaş ofis tasarımlarının günümüz yaklaşımlarıyla incelenmesini gerektirmiştir. "Bu kapsamda, 21. yüzyıla yön veren çağdaş nitelik taşıyan ofis tipolojileri fonksiyon ve tasarım şekilleriyle; Kiralanabilir Ofisler, Esnek Ofisler, Prestij Sağlayan Ofisler, Ekolojik Ofisler, Mobil Ofisler, Ev Ofisler gibi güncel yaklaşımlarla sınıflandırılabilir." (Noraslı \& Doğan, 2020, s.9)

"Çalışma alanlarının geniş, serbest düzenli ve aydınlık düzeyinin doğru hesaplanarak tasarlanması, yeni ofis mekânlarının daha fonksiyonel olmasını sağladığı gibi, iş yerlerinde serbest büro düzeni ve grup çalışmaları da, personel arası iletişim serbestliğine olanak yaratmıştır. Bu amaç doğrultusunda, ofis mekanlarında kullanıcılar ve mekan işlevi için, uygun bir aydınlatma tekniği mekanın rahat algılanması ve çalışanlarda daha yüksek verim alınması, mekandaki konfor koşullarının katkısıyla gerçekleşebilir." (Apaydın, 2012, s.1)

Çağdaş ofis anlayışına göre, bu ofis sistemlerinde zaman ve mekân kavramı gözetmeksizin bilgi akışından yararlanarak iş hareketi sağlanabilmektedir. Gelişen dünyanın, metropol şehirlerinde ilerleyen teknolojinin değiştirdiği ve çeşitlendirdiği ofis yapıları çalışma hayatının şekillenmesinde ve işleyişinde önemli görevler üstlenmiştir. "Ekonomi-politiğin tarihinde yer alan ticari eylemlerin toplumsal bağlamdaki 'öncülük' veya 'belirleyicilik' durumu bugün, üretim ilişkilerinin, teknolojiyle buluşarak bedenleştiği/mekanlaştığı yapılar olarak karşımıza ticaret/ofis yapılarını çıkarmaktadır." (Eren Özberk, 2014, s.50). Ev ofisler ise bu ticaret/ofis yapılarının insanın yaşam alanında yer bulması ile konutta herhangi bir alanın ofis haline getirilerek çalışma alanlarının iletişim ağlarının kurulup network ortamında bilgi akışının sağlanmaş ile oluşan ve istenildiği zaman yüz yüze görüşmelerin ya da toplantıların yapılabileceği ofis işlevine sahiptir. Evden çalışma düzeni ekip çalışmasına odaklı çalışmalar için uygun olmasa da bireysel çalışanlar için daha özgürlükçü bir anlayış sunmaktadır. Ayrıca işverenler açısından da ofis kirası, ofis ve personel giderleri gibi harcamalardan 
tasarruf sağlamaktadır. "Evden çalışma için "tele çalışma", "uzaktan çalışma" gibi kavramlar da kullanılmaktadır. Özellikle 90'ı yıllardan itibaren bilgisayar ve iletişim teknolojilerinde yaşanan hızlı değişim işyeri dışında bir yerde, evde çalışmayı formel sektör içerisinde de yaygın hale getirmiştir." (Kıcır, 2019, s.177)

Çağımızda yoğun seyreden salgın, deprem, sel, gibi doğal afetler kişilerin faaliyet gösterdiği çalışma alanlarını ve hatta barınma alanlarını bile değiştirmek zorunda bırakmıştır.

Yaşanan afetler kişilerin çalıştıkları ofis ortamlarından ayrılıp, yaşam alanları olan ev ortamında çalışmalarına neden olan gereksinimleri doğurmuştur. Bu çalışmada ofis ortamlarında verimliliğin artması ve konfor açısından aydınlatmanın bir türü olan sirkadiyen sistemin kurgulanmasının birey üzerindeki fiziksel ve zihinsel etkileri araştırılmıştır.

\section{Sirkadiyen Ritim}

Sirkadiyen, insan vücudunun biyolojik yapısına bağlı, insanın evrimsel gelişimini takip ederek oluşan ve günlük yaşamdaki faaliyetlerin düzen içinde devam etmesini sağlayan bir sistemdir. Sirkadiyen ritim, 2017 yılında Nobel Tıp Ödülü'nü kazanan üç bilim insanı; Jeffrey Hall, Michael Rosbash ve Michael W. Young'ın çalışmalarına sebep olan, uzun süreli bir araştırmanın sonucunda ortaya konulmuştur.

Sirkadiyen kelimesi dilimize Latince iki kavramın birleşiminden gelip yerleşmiştir. Bu iki kavram 'circa' 'yaklaşık' anlamına gelirken, 'dies' ise 'gün' sözcüğüne karşılık gelmektedir. Kelime anlamı olarak sirkadiyen yaklaşık bir günü ifade etmek için kullanılan kavramdır. Sirkadiyen ritim, insanın yaklaşık bir günü olarak kabul edilmiş zaman döngüsü içindeki fiziksel ve biyolojik değişimlerini tanımlar. Sirkadiyen ritim, insanda belirgin olarak gün döngüsü içinde incelenebilir.

"Memelilerde ritmin belirli sürelerde başlama-sonlanma döngüsünde rol alan, sirkadiyen davranış ritimlerinin oluşumu için merkezi zamanlayıcı (pacemaker) suprakiazmatik nükleus [Suprachiasmatic Nucleus (SCN)] olarak belirtilmiştir." (Welsh, Takahashi, Kay, 2010, s.2) Beyindeki suprachiasmatik çekirdek olan merkezi zamanlayıcı SCN, insan bedenindeki hareketleri, davranışları ve fonksiyonları senkronize eder ve biyolojik bir saat görevindedir. Vücut fonksiyonlarını senkronize ettirmek için gün döngüsü olan 24 saatin tamamlanmasında ışık başrolde olan bir elemandır. SCN'nin dış ortam ile uyum sağlaması için etkili olan ışık ilk olarak insan gözüyle algılanır.

Sirkadiyen ritmi etkileyen faktörler arasında başrolde bulunan ışık, sirkadiyen ritmin düzenlenmesinde, çevrenin aydınlık veya karanlık olma durumu, yani gün döngüsü önemlidir. (Fot. 1) 

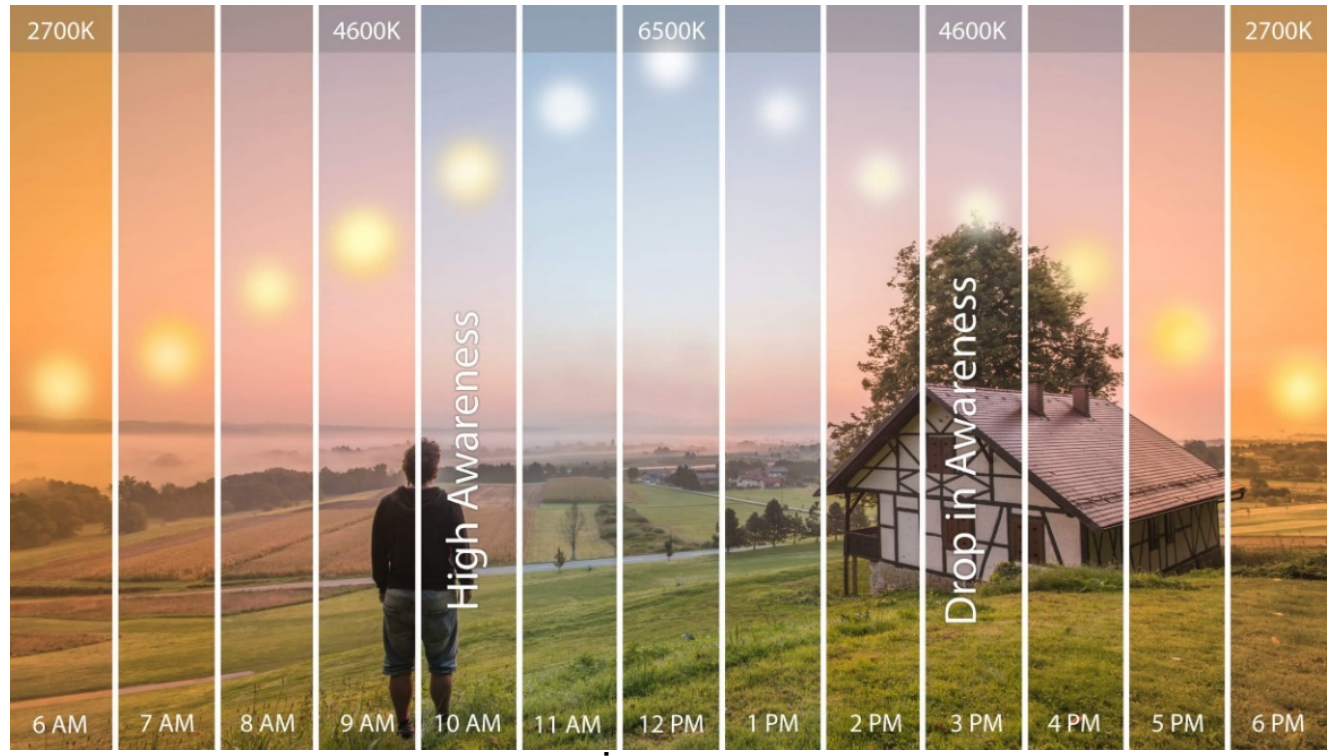

Fot. 1: Gün döngüsünde İnsanın Sirkadiyen Ritmi (URL-1)

İnsanın sirkadiyen ritmi, gece yatış ve gündüz uyanış saatlerinin bir düzen içinde biyolojik saate uygun olması gibi düzenli alışkanlıklara olduğunda en iyi sonucu verir. Bu bağlamda uzun süreli yolculuklara bağlı saat farkı değişimlerinde, uyku düzeninin bozulması ve vücudun alıştığı gece süresinde ışığa maruz kalınması veya gündüz süresinde karanlıkta olunması sirkadiyen ritmi bozabilir ve insan bedeninde birçok sağlık problemine yol açabilir.

Günümüzde yaşanılan salgın hastalığa bağlı sosyal izolasyonlar sebebiyle hayatımıza yerleşen kısıtlamalardan ötürü alışkanlıklar da değişime uğramıştır. Bu değişim insanın sirkadiyen ritmini dolayısıyla da sağlığını ve psikolojisini etkilemektedir. Özellikle günümüzde çalışma ortamı ile temel yaşam ortamı olan ev kavramının sınırlarını yitirdiği durumlarda, kişinin verimli olabilmesi için ortama etki eden tüm unsurların dikkatle ele alınması gerekmektedir.

Masa başı çalışma düzeninde kişilerin en fazla şikayet ettiği durumlardan birisi olan ergonomik tasarım kusurlarına bağlı fizyolojik rahatsızlıklar, genellikle eklem ve boyun ağrılarıdır. Uzun süre masa başında hareketsiz kalmak kişinin sağlığına zarar vermektedir. Çalışanlar mesai içinde, ofis masalarında uzun süreler yoğun tempo ile çalıştıklarında, zaman kavramını kaybedebilmektedirler. Aydınlatmanın önemi ise bu durumda ortaya çıkmaktadır. Ofis mekanlarında, gün döngüsüne bağlı ışık yoğunluğu ve sıcaklığı değişen aydınlatmalar çalışanların üzerinde tetikleyici bir rol üstlenmektedir. (Fot. 2)

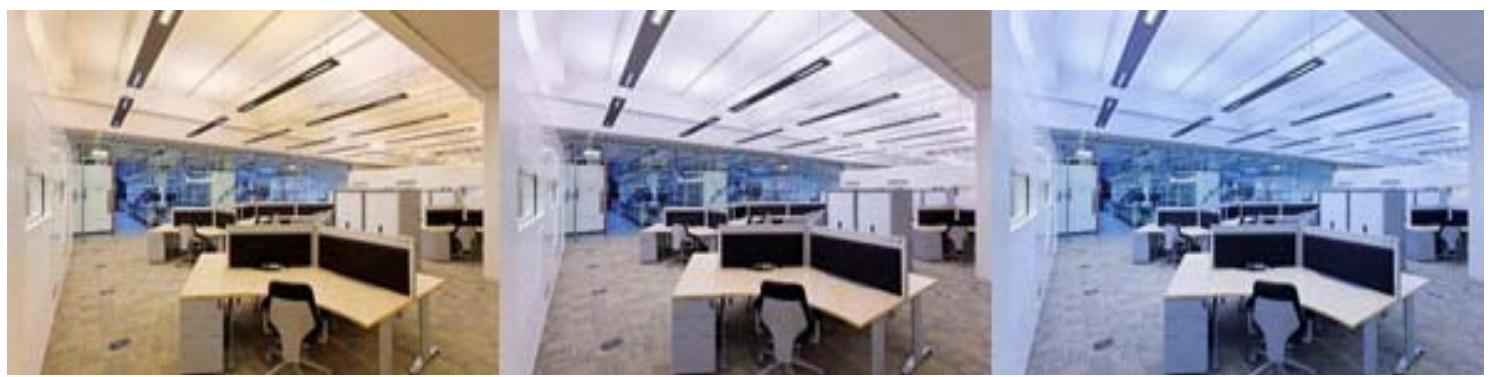

Fot. 2: Ofis Mekanlarında Sirkadiyen Aydınlatma Kullanımı (URL-2) 
Işığın içinde bulunan renk spektrumu değişikliğinin insan üzerinde uyarıcı etkisi vardır. Bu tetiklenme durumu, ofis ortamında ortalama 7.5 saat süren çalışma saatleri içinde değerlendirilerek, masa başında çalışan kişinin uyarıcı ile hareketlenip, fizyolojik ve psikolojik açıdan sağlıklı çalışması sağlanabilir.

\subsection{Sirkadiyen ritmi etkileyen faktörler}

Vücudunun oluşturduğu biyolojik saati etkileyen unsurlar kişinin zihinsel ve fiziksel sağlığını da birçok yönden etkiler. Sirkadiyen ritim olarak tanımladığımız bu saat çeşitli unsurlardan etkilenerek oluşmuştur. Merkezi zamanlayıcıyı (SCN) direkt etkileyen ışık bu bağlamda en önemli faktördür.

Bir diğer faktör olan melatonin; beynin altındaki pineal bez tarafından salınan ve insan vücudunda doğal olarak bulunup insanın uyku döngüsünü düzenleyen bir hormondur. Melatonin salınımı, karanlığa oranla, başladıktan sonra zamanla artar ve gece en üst noktaya ulaşır. Gün doğumuna doğru ise bir düşüşle sonlanır. Melatonin, organizmaya zaman bildirilmesi açısından girdi sinyali olarak görev yapar iken, salınımı SCN tarafından etkilendiğinden çıktı sinyali olarak da işlev görebilmektedir. (Fot. 3)

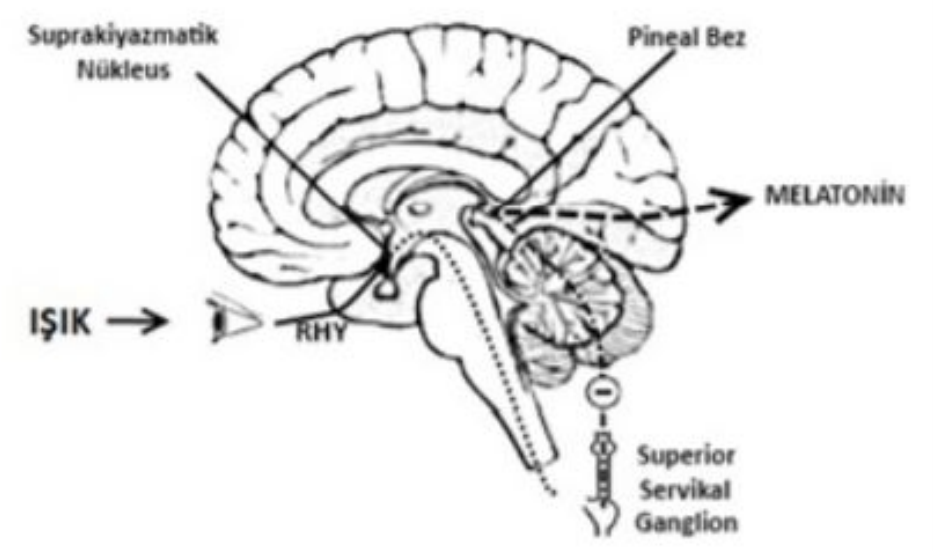

Fot.3: Işık uyarısı ile suprakiyazmatik nükleus tarafından pineal bezden melatonin sentez ve salınımı baskılanır (URL 3)

"Fizyolojideki günlük değişiklikler için sirkadiyen sinyal, SCN'den kaynaklanır. Kendi kendine devam eden sirkadyen ritim kesinlikten yoksundur. Mevcut düzende ekonomik olarak gelişmiş toplumlarda, doğal gün dönümünün son derece düzensiz bir şekilde olması yapay ışık kaynaklarının her yerde kullanımıyla ortaya çıkan açık-karanlık ortam dengesi bozulmuştur." (Reiter, Tamura, Tan, 2014, s. 322)

Farklı zaman bölgeleri arasındaki seyahatlerle oluşan jetlag insanların ritminin bozulmasının sonuçlarını tanımlar. "Jetlag, yani zaman dilimi değişikliği sendromu, genellikle uzun mesafeli uçuşlardan sonra gelişir. Aralarında belirgin zaman dilimi farkı bulunan bölgelerin hızlı bir şekilde geçilmesi, endojen sirkadiyen ritim ile çevresel koşullar arasında uyumsuzluğa neden olur ve vücut hızla değişen yeni zaman dilimine uyum sağlayamaz. Vücudun endojen ritmi, gidilen bölgedeki zaman diliminde de aynı ritmini sürdürmeye devam ettiği için uyku düzeninde ve bedensel işlevlerde geçici bozulmalar ortaya çıkar." (Akıncı \& Orhan, 2016 s.186) Seyahat başlangıcı gündüz saatinde olan kıtalararası seyahatlerde varışta yine gündüz olan bir bölgeye gitmek, insanın dinleneceği zamanda vücudunun alışık olduğu geceyi bulamadığı için başlangıçta fizyolojik ve zaman ilerledikçe psikolojik sorunlara da yol açabilir. Bu durum 
sonucunda uykusuzluk, yorgunluk, iştahsızlık, zaman algısında bozukluk gibi sıkıntılar gözlenebilir.

"İnsan, gündüz yaşama özelliği sergileyen "diurnal" bir canlıdır. Beslenme, egzersiz, çalışma gibi çoğu aktiviteyi gün içinde yapmakta ve geceleri de dinlenmektedir. İnsanlardaki içsel metabolik saat, zaman ipuçları sunarak metabolik reaksiyonlar ile planlanan aktiviteler arasında senkronizasyonu sağlamaktadır. Ancak, modern yaşamla birlikte bu hassas sistemde giderek artan değişimler meydana gelmektedir. Modern hayatın insanlara sunduğu vardiyalı çalışma saatleri, gece çalışma, gece yeme sendromu [night eating syndrome (NES)] ve uyku bozuklukları içsel ritmi bozabilmektedir." (Sözlü, Şanlıer, 2017 s. 101).

Alışkanlıklarının bozulması, bireyin günlük yaşamında hem fizyolojik hem psikolojik etkiler gösterebilir. Bu etkilerin yanı sıra biyolojik yapısıyla bağlantılı olan sirkadiyen ritim bozukluğu stres, yorgunluk ve çeşitli sağlık sorunlarına yol açabilmektedir. Sağlık sorunları insanın hayatını her alanda etkilediği gibi çalışma hayatını da etkiler. Dolaylı yoldan bu etki bireyin çalışma akışının aksamasına ve buna bağlı iş hayatındaki diğer aktörlerin olumsuz etkilenmesine sebep olur. Çalışan veya işverenlerin vücut yapısına uygun sirkadiyen ritimlerinin düzeninde olmadığı durumlarda, yaşadıkları konsantrasyon bozuklukları gibi olumsuz etkiler ilk olarak çalışma verimindeki değişimde gözlemlenir.

Değişen iklim koşullarında veya dünya üzerindeki farklı coğrafyalarda yaşanan gece gündüz eşitsizliği insan psikolojisi ve sağlığı üzerindeki etkilerini, gün döngüsünün taklit edilerek en aza indirgenmesi sirkadiyen tipi aydınlatmalar ile mümkün olabilir.

\section{Ev Ofis Mekanlarında Sirkadiyen Aydınlatma}

Beklenmeyen bir anda hayatları köklü değişime uğratan Covid-19 salgını sebebiyle dünyamız daha az evimiz olurken, evimiz daha çok dünyamız haline gelmiştir. Evlerin içine kapanmış insanlar, ofislerini de mecburen beraberlerinde getirmiştir. Günlük ortalama 7.5 saat çalışanların, evden çalışmaya geçişlerinde ise çalışma saatleri esneyip kişiye göre değişmiştir. Kimi zaman 7.5 saat sınırını aşan veya altında kalan durumlar meydana gelmiş ve uzun çalışma saatlerinde veya gündüz-gece vardiyalarında, evin içinde kalan bireyin çalışma verimi mekandaki ışık kalitesinden etkilenmiştir.

İç mekan aydınlatmaları, gün içinde gün ışığına göre değişmelidir. Ev mekanlarını ofis haline getiren insanların çalışma verimini arttırmak için öncelik insan fizyolojisi ve biyolojisine uygun bir alan yaratmak olmalıdır. Bu çerçevede, gece saatlerinde daha loş aydınlatmalar, ev içinde insanın dinleneceği saatlerde daha dingin bir mekan yaratmaya yardımcı olur. Kişinin aktif olarak çalıştığı gün içinde ise kişinin aktif tutuımasını sağlayan aydınlatmanın sıcaklık ve ışık yoğunluğu ayarı olmalıdır.

"NY, USA de bulunan Rensselaer Politeknik Enstitüsü'ndeki Aydınlatma Araştırma Merkezi (LRC), aydınlatma tasarımcıları için kurulu çevrelerde sirkadiyen ışığın anlaşılmasına ve uygulanmasına yönelik ölçümler ve araçlar geliştirmeye çalışmaktadır. Bu doğrultuda sağlıklı bina aydınlatma tasarımında önemli bir rol oynayan Circadian Stimulus (CS) denen bir ölçü geliştirmişlerdir. Ortamda olması gereken CS tanımlamasında; ışık seviyesi, renk, zamanlama, maruz kalma süresi ve fotik geçmişi (daha önceden ışığa maruz kalma süreleri) dikkate alınmalıdır. CS ölçüm değerlemeleri 0,1 ile 0,7 arasında yapılmıştır ve CS değerinin 0,3 ' den büyük olduğu 
durumlar sirkadiyen sistemin uyarılmasının en etkin olduğu değerler olarak tespit edilmiştir." (URL 4)

Ofis veya ev mekanlarında sirkadiyen aydınlatma kullanımı, güncel led aydınlatma sistemleri ile çeşitli parametrelere bağlı olarak tasarlanabilmektedir. Günümüzde çeşitli aydınlatma firmaları tarafından geliştirilen bu sistemler mekan içine yerleştirilmiş kontrol panelleri veya telefon uygulamaları gibi uzaktan kumanda yöntemleri ile de ayarlanabilmektedir. Bu aydınlatmaların çalışma prensipleri saat ayarı ile, gün içinde ışığın sıcaklığı ve yoğunluğunun artışı ve azalışına bağlı değişimlerdir. Ortamdaki ışık yoğunluğu ve sıcaklığı, aydınlatma armatürlerinde değiştirilebilen ışık ayarı ile sağlanır. $\mathrm{Bu}$ sayede, ev içindeki çalışma ortamlarında aydınlatmanın yetersizliğinden dolayı kaybedilen iş verimi ve konsantrasyon geri kazanılır.

\subsection{Tetikleme etkisi}

Dijitalleşen yaşam ile kişiler, işlerinin büyük bir bölümünü bilgisayar üzerinden yapmaktadır. Günlük yaşam pratiklerinden olan dijital eğitim, dijital alışveriş, dijital sosyalleşme gibi birçok yeni alışkanlık; dijital ekipmanlar sayesinde insan hayatının büyük bir parçası haline gelmiştir ve bu yeni alışkanlıklar insanın gün içindeki hareketlerini kısıtlamaktadır.

Masa başında geçirilen hareketsiz süre her yaş kesimi için risk oluşturmaktadır. Bu hareketsizliği ortadan kaldıracak en etkili çözüm ise mekandaki tetikleyici unsurları arttırmaktır. Uyarılar sayesinde verilen araların insanın zihinsel ve fiziksel açıdan yenilenmesine fayda sağlar. Bu araların sıklığının belirlenmesinde, aydınlatma en etkili unsurlardan birisidir.

Tetikleyici olarak seçilmiş metot olan aydınlatma etkili ve ölçülü kullanılmalıdır. Bunun için aydınlatma armatürünün bazı hususlar dikkate alınarak ayarlaması gerekmektedir: Sirkadiyen aydınlatmalarda, en yaygın kullanılan ve uygun maliyetli çözümlerden biri yoğunluk ayarı olarak kabul edilebilir. Armatürler sabit korelasyonlu renk sıcaklığını [Correlated Color Temperature (CCT)] korurken, armatürün yoğunluğu (parlaklığı) günün saatiyle ilişkilendirmek için kontrollü bir karartma sistemi aracılığıyla ayarlanır. Aydınlatma fikstürlerinin ışık yoğunluğu sabahın erken saatlerinde daha düşük olurken, gün içinde zaman ilerledikçe daha yüksek ve gün bitimine doğru ise yeniden daha düşük olacak şekilde ayarlanır.

Işık yoğunluğu ve CCT'nin değişimini sağlayan renk ayarı gün döngüsünü oluşturmak için kullanılır. Gökyüzünde güneşin konumu en yükseğe geldiğinde ve insanların en aktif, uyanık olduğu zamanda soğuk renk sıcaklıkları yaklaşık 4000K-10.000K aralığındadır. Soğuk CCT'ler bu nedenle insanların uyanıklığının ve dikkatinin tetiklenmesi gereken zamanlarda kullanılır. 2700K-3500K arasındaki sıcak renk sıcaklıkları, gün doğumu ve insanların uykuya daldığı veya gün batışı saatlerini temsil etmektedir. Sirkadiyen aydınlatma sistemi, günün herhangi bir saatinde gözlemlenen CCT'ye uygun şekilde ayarlanır. (Fot. 4)

Bir başka tetikleyici unsur olan uyaran ayarı, "kötü" mavi ışık dalgalarını "iyi" mavi ışık boylarına değiştirmeyi sağlayan aydınlatma teknolojisidir. Bu sirkadiyen aydınlatma teknolojisi, gün ışığı spektrumunu daha yakından taklit eder. Uyaran ayarı olan aydınlatma armatürleri, CCT'yi sabit tutarak, melatonin baskılamasını sınırlamak için günün ileri saatlerinde (akşam veya gece) mavi ışık dalga boylarını azaltma eğiliminde olacak şekilde ayarlanabilir. Yoğunluk ve uyaran ayarının bir arada kullanılması bu etkinin artmasını sağlar. 


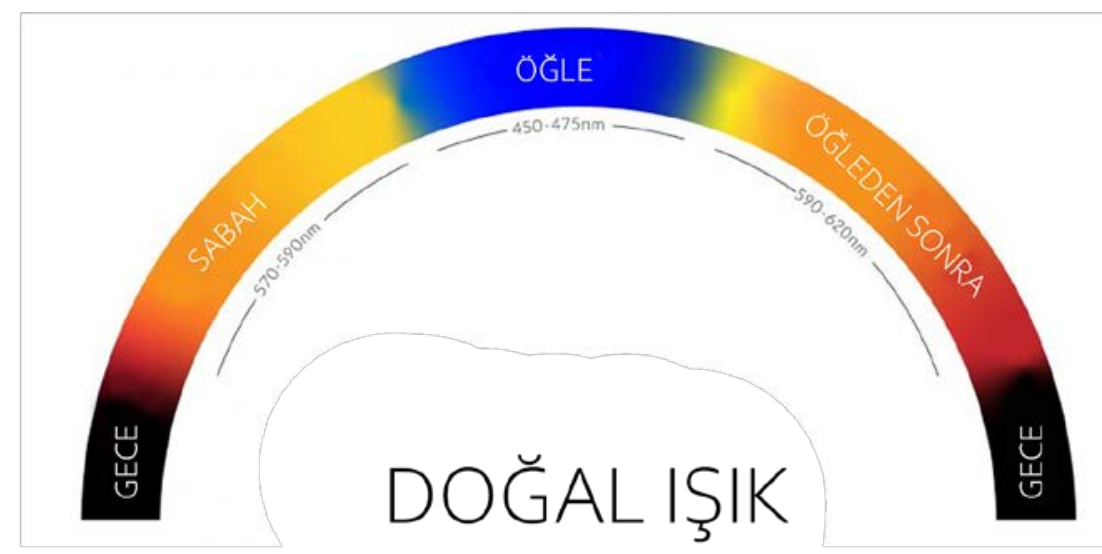

Fot. 4: Günışığının Renk Spekrumu (Çeviri URL 5)

"Gün ışığı, kamaşma gibi görsel rahatsızlıklara sebep olabilir. Bilgisayar ekranlarındaki yansımalar, rahatsız edici gölgeler termal dengeyi etkiler ve potansiyel olarak aşırı ısınmaya yol açar. Bu nedenle, doğal aydınlatma tasarımında en büyük zorluk, gün ışığı toplamanın maksimizasyonu ile bundan doğan rahatsızlık risklerinin kontrolü arasındaki dengeyi korumaktır." (Bellia, Fragliasso, Stefanizzi, 2016, s.92)

Mekandaki aydınlanma, insanın mekanı algılayabileceği ve konfor ortamını sağlayabileceği bir seviyede tutulmalıdır. Kullanılan teknolojik donanımlara direkt olarak gün ışığı veya yapay aydınlatma elemanlarının çevreye yaydığı ışık gelmemelidir. Uzun süreler ekran karşısında çalışılması ve ekrandan yayılan mavi ışığın çıplak göze verdiği zararlar kişinin yaşam kalitesini büyük ölçüde etkilediği gibi çalışmasını da olumsuz etkiler.

"İnsan odaklı aydınlatma sistemleri, çalışanların işyerinde, özellikle gün ışığının yetersiz olduğu ofislerde ve ayrıca biyolojik saatin gün ışığına zorlukla senkronize edildiği kış aylarında da rahatlık sağlayabilir. Ofis ortamlarında insan odaklı aydınlatma sistemlerinin uygulanması çalışanların daha az kaygıya sahip olmalarını, canlılıklarının artmasını, ruh hallerinin iyileşmesini, göz yorgunluklarının azalmasını ve iş tatminlerinin artmasını sağlar." (Memiş \& Ekren 2019, s. 34)

\section{Değerlendirme ve Sonuç}

Günümüzde kişilerin hazırlıksız bir şekilde toplumdan soyutlanarak evlere kapanması beraberinde hareketsizlik ile bağlantılı olmak üzere birçok sorunu ortaya çıkarmıştır. Yeni düzene uyum sağlama, evden çalışma, uzaktan eğitime devam etme gibi bireyin günlük yaşamındaki değişimler sonucunda çalışma verimliliği etkilenmiştir.

Besin maddelerinden, soluduğu havaya kadar her açıdan doğala fazlasıyla ihtiyaç duyan insan bedeni, aynı zamanda intiyacı olan gün döngüsünü kaçırmaya başlamıştır. Özellikle kısıtlı alanlara sıkıştırılmış küçük ölçekli konutlar, ışıktan uzak yerleşkeler, yanlış oluşturulmuş şehir planlamaları birbiri ile bitişik yapılar, iç mekanlarda kişileri psikolojik rahatsızlıklara itmektedir.

Dijitalleşen ve günden güne alışılan normal döngüsünden uzaklaşan insanın intiyacı olan döngüsel düzenleme yapay aydınlatma ile sağlanır. Bu aydınlatma teknolojisi, yapay ışığın insanın sirkadiyen ritmi üzerindeki etkisini düşük seviyelere indirerek insan sağlığını korumayı amaçladığından ev ve ofislerde daha çok tercih edilmelidir. 
Sirkadiyen ritim, bireylerin yaşadıkları mekan içindeki çalışma ortamlarında oluşacak fiziksel ve zihinsel sorunları ortadan kaldırabilecek bir rol üstlenmektedir. Bireyin çalışma ortamında geçirdiği sürede fiziksel ve zihinsel rahatsızlıklardan korunması sirkadiyen aydınlatma tasarımları ile sağlanır. İnsan odaklı aydınlatma kavramı çerçevesinde ele alınmış olan sirkadiyen aydınlatma sistemi, dışarıdaki gün döngüsünü ev içerisinde oluşturur ve insanın evde çalışma ortamında optimum konsantrasyon düzeyinde kalmasını sağlayarak iş veriminin artmasına katkı sağlar.

Sirkadiyen ritmin normal döngüsünde olmaması durumunda uyku düzeninde bozulmalar, performans düşüklüğü, diyabet, hormonal dengesizlikler, vücut Isı değişiklikleri ve bazı kanser türlerine karşı riskin artması gibi birçok problem görülebilir. Bu gibi problemlerden kaçınmak için kullanılabilecek sirkadiyen aydınlatmalarda dalga boyları günün farklı saatlerinde değiş̧erek, gündüz saatlerinde bireyin konsantrasyonunu, tepki verme sürelerini ve ruh durumunu iyi yönde etkilenmektedir. Gece saatlerinde ise rahatsız edici etkisi olabileceğinden, uyarıcı bir aydınlıktan dinlendirici bir karanlığa geçmesi sağlanmalıdır.

Geleneksel aydınlatma tasarım anlayışında mekanın görsel algısı, parlaklık ve kamaşma kontrolü, ışık kirliliği ve enerji verimliliği gibi konulara odaklanıııken sirkadiyen aydınlatmada ise aktiflik, tetiklenilme gibi görünür olmayan etkiler en önemli faktörlerdendir. Bu durum da günümüz tasarımcılarının geleneksel aydınlatma tasarımının yanında sirkadiyen aydınlatma sistemlerini de göz önünde bulundurmalarını gerektirir.

\section{Kaynaklar}

Akıncı, Erhan \& Orhan, Fatma Özlem, (2016). Circadian Rhythm Sleep Disorders. Psikiyatride Güncel Yaklaşımlar, 8 (2), 178-189. DOI: 10.18863/pgy.81775

Altınkoç, Yaprak Özel, "Büro Binaları ve Tasarımında Temel İlkeler ve İç Mekan Organizasyonu", Mimar Sinan Güzel Sanatlar Üniversitesi Fen Bilimleri Enstitüsü İç Mimarlık Ana Bilim Dalı, Yüksek Lisans Tezi, İstanbul 2005.

Apaydın, Serpil, "Ofislerde Aydınlatma Tasarımının Sürdürülebilirlik Açısından Mekân Tasarımına Etkileri”, Haliç Üniversitesi Fen Bilimleri Enstitüsü İç Mimarlık Ana Bilim Dalı, Yüksek Lisans Tezi, İstanbul 2012.

Aytar Sever, İldem \& Çelebi Şeker, Nida, "Sosyal Bilimlerde Yeni Araştırmalar", ISBN: 978-605-7634-26-9, Berikan Yayınevi, s.533-541, Ankara 2019.

Bellia, Laura, Fragliasso, Francesca \& Stefanizzi, Emanuela, (2016). Daylit offices: A Comparison Between Measured Parameters Assessing Light Quality and Users Opinions, Building and Environment, (113), s.92-106, ISSN 0360-1323. DOI: 10.1016/j.buildenv.2016.08.014.

Eren Özberk, İmre, (2014). Ofis Yapıları Tasarımında Deneysel Bir Alan Olarak Yapı Kabuğu, Mimarist, (49), s.50, İstanbul.

Kıcır, Başak, (2019). Evden Çalışma: Özgürlük mü Esaret mi?. Dokuz Eylül Üniversitesi Sosyal Bilimler Enstitüsü Dergisi, 21 (1), 173-196. DOI: 10.16953/deusosbil.302154 
Memiş, Özge \& Ekren, Nazmi, (2019). İnsan Odaklı Aydınlatma, International Periodical of Recent Technologies in Applied Engineering, 1 (1), 30-35. Erişim adresi: https://dergipark.org.tr/en/pub/porta/issue/44896/542862.

Norası, Mehmet \& Köse Doğan, Rabia, (2020). Çağdaş Ofis Tasarımları Üzerine Bir İnceleme, Bee Rendering Tasarım Ofisi, Artium, 8 (1), 1-10, Erişim adresi: http://artium.hku.edu.tr/tr/pub/issue/52425/568801

Reiter, J. Rüssel, Tamura, Hiroshi, Tan, Dun Xian \& Xu, Xiao-Ying, (2014). Melatonin and the Circadian System: Contributions to Successful Femalere Production. Fertility and Sterility, 2 (102), s.321-8, ISSN 0015-0282. DOI: 10.1016/j.fertnstert.2014.06.014.

Sözlü, Saniye \& Şanlıer, Nevin, (2017). Sirkadiyen Ritim, Sağlık ve Beslenme İlişkisi, Türkiye Klinikleri Sağlık Bilimleri Dergisi, 2(2), 100-109. DOI: 10.5336/healthsci.201548902.

Welsh, K. David, Takahashi, S. Joseph \& Kay, A. Steve, (2010). Suprachiasmatic Nucleus: Cell Autonomy and Network Properties. Annu Rev Physiol; 72(1), s.551- 77. DOI: 10.1146/annurev-physiol-021909-135919.

\section{INTERNET KAYNAKLARI}

URL-1 https://www.thelighting practice.com/what-is-circadian-lighting/

URL-2 https://hoarelea.com/2019/01/15/the-ultimate-guide-to-circadian-lighting/

URL-3 http://www.cappsy.org/archives/vol8/no2/cap_08_02_08.pdf

URL-4 http://www.zeve.com.tr/insan-odakli-aydinlatmanin-onemi-nedir-fikret-ersan-talu

URL-5 https://hoarelea.com/2019/01/15/the-ultimate-guide-to-circadian-lighting/ 